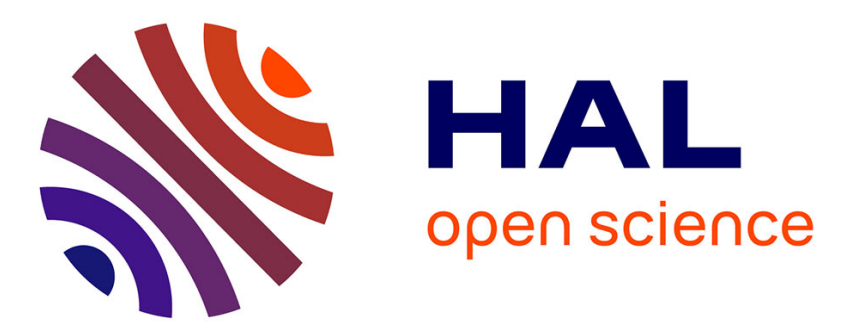

\title{
Global assessment of the technological risks relative to the transport and the storage of chemical products
}

Raphaël Defert, Emmanuel Ruffin

\section{To cite this version:}

Raphaël Defert, Emmanuel Ruffin. Global assessment of the technological risks relative to the transport and the storage of chemical products. 11. International Symposium on Loss Prevention and Safety Promotion in the Process Industry, May 2004, Praha, Czech Republic. pp.4269-4272. ineris00972455

HAL Id: ineris-00972455

https://hal-ineris.archives-ouvertes.fr/ineris-00972455

Submitted on 3 Apr 2014

HAL is a multi-disciplinary open access archive for the deposit and dissemination of scientific research documents, whether they are published or not. The documents may come from teaching and research institutions in France or abroad, or from public or private research centers.
L'archive ouverte pluridisciplinaire HAL, est destinée au dépôt et à la diffusion de documents scientifiques de niveau recherche, publiés ou non, émanant des établissements d'enseignement et de recherche français ou étrangers, des laboratoires publics ou privés. 


\title{
Global Assessment of the Technological Risks Relative to the Transport and the Storage of Chemical Products
}

\author{
DEFERT Raphaël (Civil Engineer - Safety in Transport System), RUFFIN Emmanuel (Program \\ manager for Tunnel Safety and Transportation of Hazardous Goods) \\ Institut National de l'Environnement Industriel et des Risques (INERIS), Parc Technologique Alata - \\ BP 2, 60550 Verneuil-en-Halatte, FRANCE \\ Raphael.Defert@ineris.fr, tel: +33 3445562 05, fax: +33 344556295
}

\begin{abstract}
Industrial activity requires the production and the use of dangerous goods in the chemical plants. It also requires their transport between these installations. These products thus present risks on the plants sites, but also between them, because of their transport. Today, regulations constrain chemical plants to minimise their risks. This is in this context that the GLOBAL project will examine how the logistic strategies of the industrialists can influence the risks due to the transport of dangerous goods. For example, by minimising the quantities stored in the fixed installations, does one increase the risks due to transport and in this case, up to what point? The objective of the present research is to examine new risks assessments methods of quantification that could be applied both for the fixed installations and for transport, and then bring global answers.
\end{abstract}

\section{Introduction}

The need for development brings forth technological progress but simultaneously induces risks that cannot be completely avoided. The impact on health, environment and economy must thus be approached. One can quote the examples of Seveso, Bhopal, the tunnel fires of the Tauern and the Mont Blanc, etc. This shows the need to analyse and to assess systematically all the types of risks in order to protect the public health and to limit the environmental and economic impacts of potential accidents. However, the impacts (in term of risk) of these technologies should not be treated independently of the benefits that they bring to the society. The respective weight of the risks and of the benefits is fundamental for any decision-making process. The different risk assessment methods provide qualitative and quantitative measurements that can constitute a support for the decisionmaking. The technological risks are treated differently according to the different activities and existing pertaining regulations. Several national and international organisations use methods to be applied in various activities (chemical plants and transport). However, these methods are often specific to the sectors to which they are applied and adopt frequently various definitions, models and approaches to assess the risks.

\section{The problematic}

\subsection{State of the art: a lack of harmonisation}

It is obvious that there is a lack of harmonisation in risk assessment. Because of the differences of culture in the different countries and in the different fields (transport, fixed installations, etc.) that requires risk-assessment, it is not simple to find a common methodology. But it would improve the transparency in decision-making.

Technological risks are treated differently in the different fields of activity and in the different countries. For example, the use of deterministic or probabilistic methods depends on where you live and which industry you are looking at. Decision-makers have to deal with a variety of approaches to assess and manage a specific risk, which makes the comparison of risk studies performed by different organisations a difficult task. 
In order to illustrate this lack of harmonisation, in the Netherlands, probabilistic risk analysis is a requirement of the safety report. The Netherlands have a clearly defined policy on the maximum levels of risk that are acceptable when considering land-use decisions. In the UK, the probabilistic approach to risk analysis is favoured, but up to now, quantitative risk criteria have been published only as far as the control of land-use in the vicinity of industrial facilities is concerned, whereas criteria for siting of new activities are being developed. In Germany, deterministic approaches are extensively used in the chemical process industry to demonstrate the quality of the measures taken to avoid risk inside and outside the installation. Safety decisions, both with regard to design and operation, are made on the basis of the potential consequences alone, independent of an explicitly defined probability.

\subsection{How to assess globally the industrial risks?}

The industrial activity requires the production and the use of dangerous products and goods in the chemical plants. It also requires their transport between these installations. These products thus present risks in the industrial sites, but also between these sites, because of their transport.

Today, the regulations concerning chemical plants logically constrain the operators to minimise the risks. The risks relative to the transport and to the installations of temporary storage are for their part limited by regulations such as the ADR, the RID, the IMDG, etc. But these risks are not treated by specific studies. New texts of law and European draft Directives are in hand to mitigate partially these lacks. In this context, it is appropriate to examine how the exploitation strategies of the chemical plants can influence the risks due to the Transport of Dangerous Goods (TDG). For example, by minimising the quantities stored inside the sites, does one increase the transport risks and in this case, up to what point? For this purpose, the present project will examine different quantitative risks assessment methods that, applying on chemical plants and also in the fields of transport (road transport, rail transport, etc.), can bring global answers.

\section{The GLOBAL project}

\subsection{Context of the project}

INERIS has carried out and still carries out many projects linked with the assessments of the risks due to chemical plants and transport of dangerous goods. In this context, the Accidental Risks Division carries out a program entitled "GLOBAL" which means "Global evaluation of the technological risks relative to transportation and storage of chemical products". This project was adopted by the ministry for spatial planning and environment that will bring a part of the financing.

\subsection{Purpose}

The purpose of the project is to examine the ways risk assessments for the systems of transport and the chemical plants are performed and then to analyse the practices of risk management based on these evaluations. The work will consist in setting up a method based on a single risk assessment principle, which will be applicable at the same time on transport activities and on storages. From the criteria of existing risk management in the two fields, the work will consist in proposing new indicators or criteria that could facilitate the arbitrages and allow the comparison of the risks. It will also consist in using the method to give a first opinion on the global benefit that can be withdrawn from strategies consisting in reducing the size of the storages in the sites.

Philosophies and methods of risk management on the chemical plants and on the means of transport are very different. However, the interactions between these fields are strong, and one cannot reasonably claim to manage the whole industrial risks and ignore one of these fields. The project suggested is innovating insofar as only few parallels and comparisons were carried out until today between these fields. Moreover, the probabilistic aspects, which could be approached in this program, are developed very little with regard to the safety reports of chemical plants. 


\subsection{Content of GLOBAL}

The GLOBAL project contains several tasks that are listed below:

- Description of the activities of transport and chemical plants.

The objective is to describe these two types of fields, from a quantitative and a qualitative point of view: flows, means of transport, sizes of the storage, packaging, etc. For a few main products (because of their dangerous character or of their importance in the flews), the methods of production, consumption and transport will be detailed (producing and consuming areas, seasonal character, usual means of transport, etc.)

- Description of the regulation context.

Indeed, it is useful to confront these two fields taking into account the regulations applicable. It will make it possible to better understand the differences that exist between the philosophies. The purpose is to point out the historic of the various regulations applied in transport (ADR, RID, etc.) and for fixed installations, then to draw up a synthetic inventory of the current regulations. In this operation, the work will not consist in reproducing in extenso the regulations applying in the two fields, but in revealing the similarities or the differences with regard to these questions of major risks.

- Learning from experience and statistical analyse of the past accidents.

In order tound erline the differences existing between the fixed and the mobile installations, INERIS proposes to undertake a compared study of the accidents resulting from these two fields. That is to say: existing databases (sources, mode of data collecting, etc.), compared uses of these bases, and compared analyse of the accidents (kind of accident, gravity, etc.).

- Current methods of risk assessment in the fields of transport and of chemical plants.

The risk management requires its identification and its assessment with a taking into account of the means able to reduce either gravity, or the frequency of occurrence. Straightaway, the methods used to identify, assess and manage the risks in the field of chemical plants and transport seem notably different. Therefore, this operation will be lead to study the different approaches of risks assessment in the two fields, in particular by presenting the methods used, the principles which justify them and the models most frequently used, by describing their fields and their application limits.

- Analyse of the various possible policies.

The purpose is to study a few cases which induced a transfer of risk from the fixed installations towards freight vehicles of dangerous goods, for example by decreasing the quantity stored in the fixed installations and by increasing the quantity stored temporarily in the bulks. It will consist in understanding the mechanisms of the transfer, judging their interest and their disadvantages, finding means of avoiding them if the disadvantages are significant, and then considering total solutions of management of the dangerous goods. At the end of this operation, several common cases, i.e. installations presenting similar logistic modes (for certain sectors of activity for example), could be highlighted. This operation could also be useful to bring together decisionmakers and industrialists to have a better vision of the existing practices.

\section{- Global method of assessment.}

In this operation, the purpose consists in thinking about the conditions that would make it possible to compare the risks relative to transport and fixed installations. These activities are different and the risks assessments methods also, but to assess the total risk, a common method, simple but elaborated enough, should be found. It is particularly difficult to achieve, because if the uncertainties are too significant, this kind of method could be unusable to allow decisions. From the criteria existing for the risk management in the two fields, the aim will be to propose new indicators or criteria that could facilitate the decisions and allow the comparison of the risks. If the results of these investigations are sufficiently interesting, a case study could then be then considered. 


\section{References}

1. Promotion of Technical Harmonisation on Risk-Based Decision Making. Stresa \& Ispra, Italie, 2225 May 2000

2. O.Salvi (INERIS). Propositions pour la Révision du Guide de Maitrise de l'Urbanisation, 2001

3. R.Defert (INERIS). Modèle d'évaluation quantitative des risques liés au transport routier de marchandises dangereuses - application aux études comparatives de risques. Symposium "Risque d'accidents et risques environnementaux dans les transports terrestres", 11-12 October 2001

4. P. Cassini - P. Pons - R. Defert (INERIS). "Mise au point d'un modèle d'Analyse Quantitative des Risques $(\mathrm{AQR})$ liés aux transports de matières dangereuses sur différents itinéraires alternatifs à l'air libre ou en tunnels". Organisation for Economie Co-operation and Development (OECD)

5. ARIA Database. BARPI

6. MTMD Database. Mission Transport des Matières Dangereuses

7. Code de l'environnement. MEDD

8. Circulaire interministérielle $n^{\circ} 2000-63$ relative to the security in road tunnels, 25 August 2000.

9. Circulaire interministérielle $\mathbf{n}^{\circ} 2000-82$ relative to the traffic of Dangerous Goods Vehicles through road tunnels, 30 November 2000.

10. World Road Association (PAIRC) 